\title{
Description of hypoeutectic Al-Si-Cu alloys based on their known chemical $_{\text {compositions }}^{(\bullet)}$
}

\author{
M.B. Djurdjevic* and I. Vicario**
}

\begin{abstract}
The modeling of casting processes has remained a topic of active interest for several decades, and the availability of numerous software packages on the market is a good indication of the interest that the casting industry has in this field. Most of the data used in these software packages are directly read or estimated from the binary or multi-component phase diagrams. Unfortunately, except for binary diagrams, many of ternary or higher order phase diagrams are still not accurate enough. Having in mind that most of the aluminum binary systems are very well established, it has been tried to transfer multi-component system into one well known Al-Xi pseudo binary system (in this case the Al-Si phase diagram was chosen as a reference system). The new Silicon Equivalency $\left(\mathrm{Si}_{\mathrm{EQ}}\right)$ algorithm expresses the amounts of major and minor alloying elements in the aluminum melts through an "equivalent" amount of silicon. Such a system could be used to calculate several thermo-physical and solidification characteristics of multi component as cast aluminum alloys. This provides to the model the capacity to predict the solidification characteristics of cast parts, where cooling rates are slow and the solidification process has to be known in great detail in order to avoid quality problems in the casting. This work demonstrates how the $\mathrm{Si}_{\mathrm{EQ}}$ algorithm can be used to calculate the characteristic solidification temperatures of the multicomponent Al-Si alloys as well as their latent heats and growth restriction factor. Statistical analysis of the results obtained for a wide range of alloy chemical compositions shows a very good correlation with the experimental data and the $\mathrm{Si}_{\mathrm{EQ}}$ calculations. The same mathematical approach might be applied for other metallic systems such as iron and magnesium, using carbon equivalency for ferrous systems and aluminum equivalency for magnesium multi-component alloys.
\end{abstract}

\section{Descripción de las aleaciones hipoeutécticas Al-Si-Cu basada en su composición química}

\begin{abstract}
Resumen
La modelización de los procesos de fundición ha sido un tópico de interés durante las últimas décadas, y la cantidad de programas de simulación existentes en el mercado es un buen indicador del interés de la industria en este campo. La mayoría de los datos empleados en estos programas se basan en los diagramas de fase binarios, ternarios o incluso superiores. Desafortunadamente, excepto para los diagramas binarios, el ajuste de los datos no es lo suficiente bueno. Teniendo en cuenta que la mayoría de los sistemas binarios del aluminio están bien definidos se ha intentado convertir los sistemas multi-componentes en un pseudo binario sistema Al-Xi (en este caso el diagrama de fase Al-Si es el elegido como sistema de referencia). El nuevo algoritmo del Silicio Equivalente $\left(\mathrm{Si}_{\mathrm{EQ}}\right)$ expresa la cantidad de los elementos de la aleación que son mayoritarios y minoritarios, a través de una cantidad "equivalente" de silicio. Este sistema puede emplearse para calcular varias características termo-físicas y de solidificación de sistemas multicomponentes, como las aleaciones de aluminio. Esto permite al modelo tener la capacidad de realizar predicciones de las características de la solidificación de las piezas fundidas, donde las velocidades de enfriamiento son bajas y las características del proceso de solidificación son bien conocidas, para evitar posibles problemas en la fundición. Este trabajo demuestra cómo el algoritmo del $\mathrm{Si}_{\mathrm{EQ}}$ puede ser empleado para el cálculo de las características de las temperaturas de solidificación de las aleaciones multi-componentes $\mathrm{Al}-\mathrm{Si}$, así como sus calores latentes y el factor de restricción del crecimiento del grano. El análisis estadístico de los resultados obtenidos en un amplio rango de composiciones químicas de la aleación, muestra una muy buena correlación entre los datos experimentales y los cálculos realizados con el $\mathrm{Si}_{\mathrm{EQ}}$. La misma aproximación matemática podría ser aplicada para otros sistemas metálicos como el hierro y el magnesio, empleando el carbono equivalente en el caso de los sistemas base hierro y de la equivalencia con el aluminio para las aleaciones multi-componentes base magnesio.
\end{abstract}

Palabras clave

(•) Trabajo recibido el 25 de junio de 2012 y aceptado en su forma final el día 14 de marzo de 2013.

* Nemak Europe GmbH, The Squair 17 am Flughafen, 60549 Frankfurt, Germany.

**Tecnalia, Paseo de Mikeletegi, 2 - 20009, San Sebastián. E-mail: iban.vicario@tecnalia.com 


\section{INTRODUCTION AND SCOPE}

The modeling and control of casting processes has remained a topic of active interest for several decades, and the availability of numerous software packages (Magma, Thermo-Calc, Fact-Sage, ProCast, Calphad, Pandat, WinCast etc.) on the market, are a good indication of the interest that casting industries and researchers have in this field. Most of the data used in the above listed software packages are based on binary or multi-component phase diagrams but unfortunately, except for binary diagrams, many of the ternary or higher order phase diagrams are still not accurate enough for this purpose. Keeping in mind that most of aluminum binary systems are very well established, the transferring of a multi-component system into a well known Al-Xi "quasi-binary" system has great industrial and research potential. This type of system could be used to calculate several thermo-physical and solidification process parameters of multicomponent aluminum alloys in as cast or melt treated conditions. In order to calculate the various thermo-physical and metallurgical parameters of a solidifying aluminum casting alloys, the characteristic solidification temperatures of the alloy must be known with the highest degree of accuracy. Unfortunately, few equations are reported in the literature that relates the compositions of many commercial hypoeutectic aluminum-silicon series of alloys for their liquidus ${ }^{[1-3]}$ and eutectic ${ }^{[4]}$ temperatures.

The cast Al-Si alloys are widely used in many automotive components. These alloys are characterized by their low density, light weight, relative low melting temperatures, negligible gas solubility (with the exception of hydrogen), excellent castability, good corrosion resistance, good electrical and thermal conductivity and good machinability. Major alloying elements silicon, copper and magnesium are responsible for defining the microstructure of aluminum alloy. Silicon is added to improve castability, fluidity, to reduce shrinkage and to give superior mechanical properties. The presence of copper improves tensile strength at the expense of a reduction in ductility and corrosion resistance. Magnesium is purposely added into aluminum alloys to increase their hardness and strength after heat treatments. Manganese controls the intermetallic form of iron phase, leading to an improved ductility, strength at high temperature and casting soundness. Iron is a major impurity element in this type of aluminum alloys. In high concentration it decreases ductility, castability and machinability of aluminum alloys. Minor alloying elements such as strontium, sodium, boron, titanium and tin are added into aluminum melt to improve structural and mechanical properties of cast parts. All these major and minor alloying elements have significant impact on the solidification path of any particular aluminum alloy.

The Al-Si phase diagram is the base component system for this series of alloys. This is a binary eutectic type phase diagram with limited aluminum and silicon solubility. The solubility of silicon in the aluminum melt reaches a maximum of $1.6 \mathrm{wt} . \%$ at the $577^{\circ} \mathrm{C}$ eutectic temperature. The maximum solubility of aluminum in silicon at the eutectic temperature is still questionable, and according to some literature data is approx. $0.015 \%{ }^{[5]}$. The concentration of silicon, which corresponds to the eutectic reaction, is still not accurately defined or accepted among researchers, despite the fact that this diagram has been investigated often. In the available literature the following values for eutectic concentration of silicon were found: 11.9 wt.\% ${ }^{[6]}, 12.3$ wt. \% ${ }^{[7]}$ and 12.6 wt. $\%{ }^{[8]}$. In this work the value of 12.3 wt. \%. of silicon will be used as the eutectic concentration of silicon as well as $577^{\circ} \mathrm{C}$ the temperature at which eutectic reaction occurs.

The purpose of this paper is to develop a general method for the calculation of the characteristic solidification temperatures (liquidus temperature, Al-Si and Al-Si-Cu eutectic temperatures) of multi-component hypo Al-Si alloys, based on their chemical composition. The accuracy of the developed algorithms will be determined by comparing the calculated values of the solidification characteristic temperatures with the measured values obtained using thermal analysis technique. In addition the various software packages will be used to calculate characteristic solidification temperatures and obtained results will be compared with temperatures calculated using $\mathrm{Si}_{\mathrm{EQ}}$ procedure. Applicability of the equivalency algorithm to calculate some other thermo-physical properties (latent heat) or structural properties (growth restriction factor) of aluminum alloys will be also briefly discussed in this paper.

\section{DEVELOPMENT OF THE SILICON EQUIVALENT $\left(\mathrm{Si}_{\mathrm{EQ}}\right)$ ALGORITHM}

The liquidus and solidus temperatures of the Al-Si phase diagram decrease uniformly with the increase in the amount of silicon, and reach the minimum at the eutectic composition (12.3 wt.\%). The same behavior can be observed in the liquidus and solidus 
lines in most binary eutectic types of aluminum alloys as presented in figure $1^{[8]}$.

Mathematically, the liquidus line of any eutectic binary $\mathrm{Al}-\mathrm{Xi}$ phase diagrams from figure 1 can be accurately expressed by the second polynomial order as follows:

$$
\mathrm{T}_{\mathrm{LIQ}}^{\mathrm{Al}-\mathrm{Xi}}=\mathrm{A}-\mathrm{B} \cdot \mathrm{Xi}-\mathrm{C} \cdot \mathrm{Xi}^{2}
$$

where:

$\mathrm{T}_{\mathrm{LIQ}}^{\mathrm{Al}-\mathrm{Xi}}$ : is the liquidus temperature of binary Al-Xi system, ${ }^{\circ} \mathrm{C}$.

$\mathrm{Xi}$ : is the amount of the alloying element in wt.\%. $\mathrm{A}$ : is the melting point of pure aluminum: $660.452^{\circ} \mathrm{C}$.

\section{B, C : are polynomial coefficients.}

Therefore, the liquidus line for the Al-Si binary system can be expressed respectively as follows:

$$
\mathrm{T}_{\mathrm{LIQ}}^{\mathrm{Al}-\mathrm{Si}}=660.452-6.11 \cdot \mathrm{Si}-0.057 \cdot \mathrm{Si}^{2}
$$

The visual analysis of two liquidus lines of the binary systems, $\mathrm{Al}-\mathrm{Si}$ and $\mathrm{Al}-\mathrm{Xi}$ as presented in figure 2, shows that the "equivalent effect" on the liquidus temperature of the aluminum alloy can be obtained by using "equivalent" concentrations of silicon and $\mathrm{Xi}$ alloying elements.
This means that the influence of any alloying element in the aluminum melt on its liquidus temperature can be expressed as the effect of an "equivalent amount" of silicon (wt \%). The isothermal concentration difference between the silicon and $\mathrm{Xi}$ alloying elements can be mathematically expressed as follows:

$$
\mathrm{Si}^{\mathrm{Xi}}{ }_{E Q} @ \mathrm{QT}=\text { CONSTANT }=\mathrm{Si}(\mathrm{wt} \%)-\mathrm{Xi}(\mathrm{wt} \%)
$$

Silicon as the major alloying element for Al-Si alloys was chosen as the reference element. It is also known that it has the most significant influence on the casting properties of Al-Si family of alloys (e.g. fluidity, latent heat and shrinkage).

Taking into consideration the whole temperature range between the melting temperature of pure aluminum and the eutectic temperature of an observed binary alloy, the following relationship can be established between $\mathrm{Si}{ }^{\mathrm{Xi}}{ }_{\mathrm{EQ}}$ and the concentration of the alloying element $\mathrm{Xi}$ :

$$
S{ }^{X i}{ }_{E Q}=a_{0}{ }^{X i}+b_{0} X^{X} X i+c_{0}^{X i} X i^{2}
$$

where:

$\mathrm{Si}^{\mathrm{Xi}}{ }_{\mathrm{EQ}}$ : is the silicon equivalent for any alloying element expressed in wt.\%

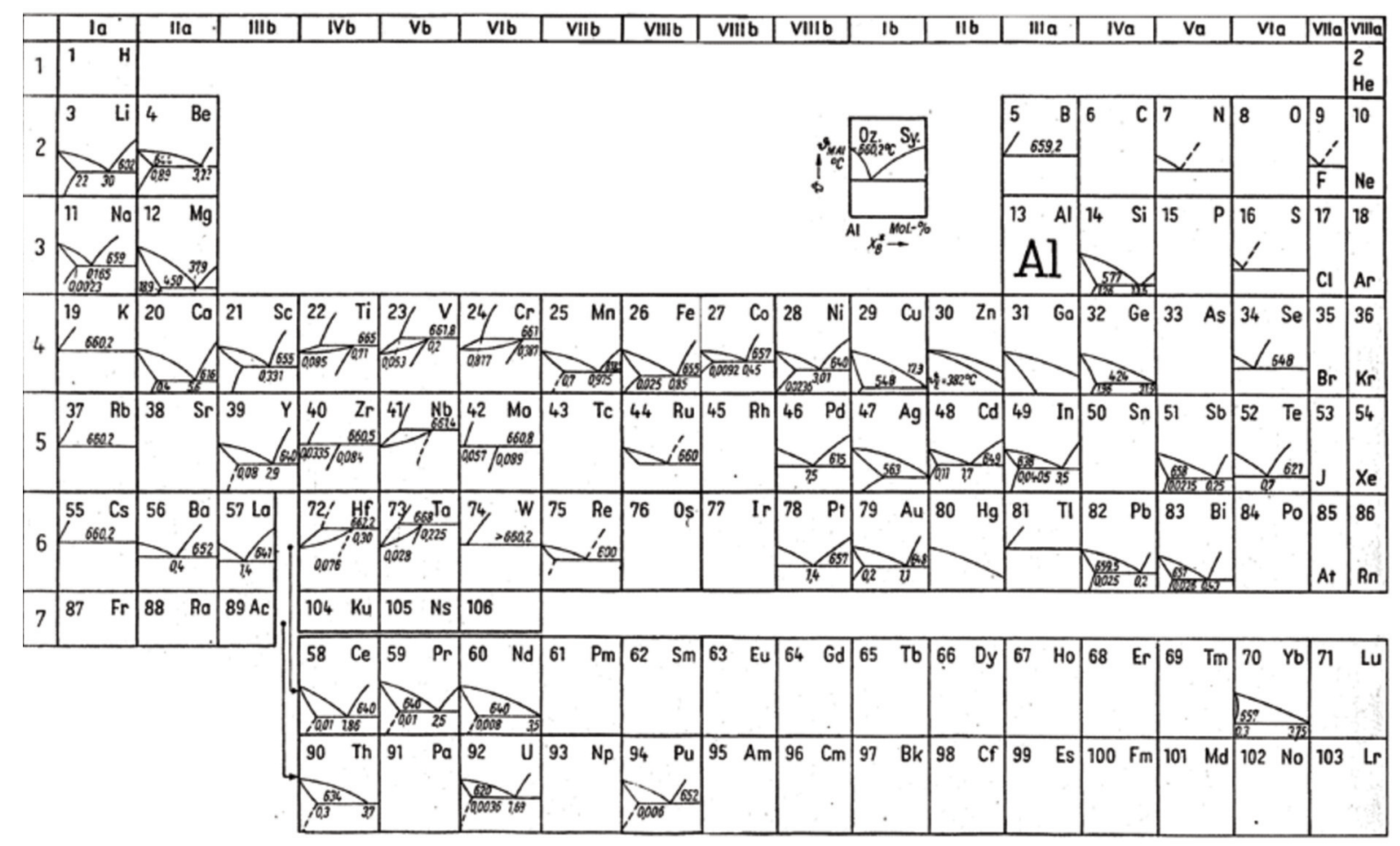

Figure 1. Al-Xi binary phase diagram ${ }^{[8]}$.

Figura 1. Diagrama de fases binario Al-Xi ${ }^{[8]}$. 


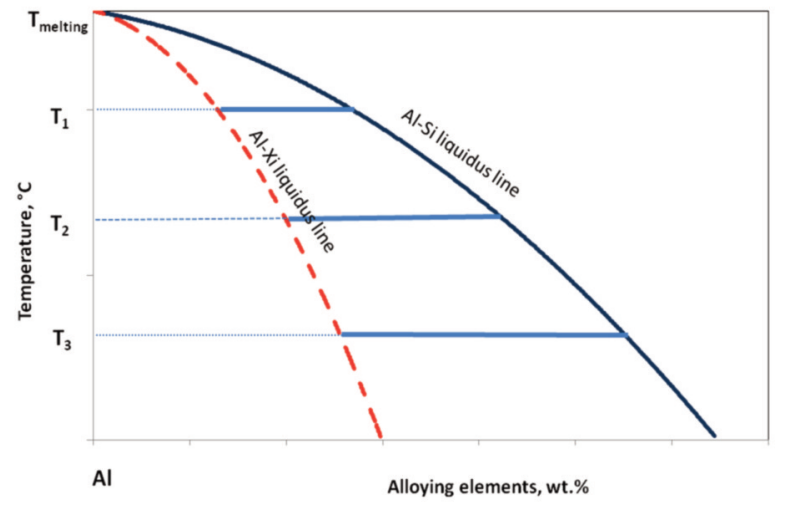

Figure 2. Superimposed liquidus lines of Al-Si and $\mathrm{Al}-\mathrm{X}_{\mathrm{i}}$ binary systems.

Figura 2. Líneas de liquidus superpuestas de los sistemas binarios Al-Si y Al- $X_{i}$.

$a_{0}{ }^{X i}, b_{0} X_{i}, c_{0}{ }^{X_{i}}$ : polynomial coefficients for considered alloying element

$\mathrm{Xi}$ : the concentration of alloying elements in wt.\%

Figures 3 a) and 3 b) summarize the effect of some major, minor and other elements, such as impurities, grain refiners or silicon modifiers on the $\mathrm{Si}^{\mathrm{Xi}}{ }_{\mathrm{EQ}}$. Their effect has been expressed in the polynomial form according to equation (4).

The strongest effect on $\mathrm{Si}_{\mathrm{i}} \mathrm{Xi}_{\mathrm{EQ}}$ is produced by manganese (Fig 3 a)). The effect of the other major alloying elements on it decreases in the following order: iron, nitrogen, copper, zinc, calcium and magnesium respectively. This order corresponds to the slope value $(\Delta \mathrm{T} / \Delta \mathrm{Xi})$ of liquidus line for a particular binary Al-Xi phase diagram. The effect of some other elements on the value of $\mathrm{Si}_{\mathrm{EQ}}{ }_{\mathrm{X}}$ has

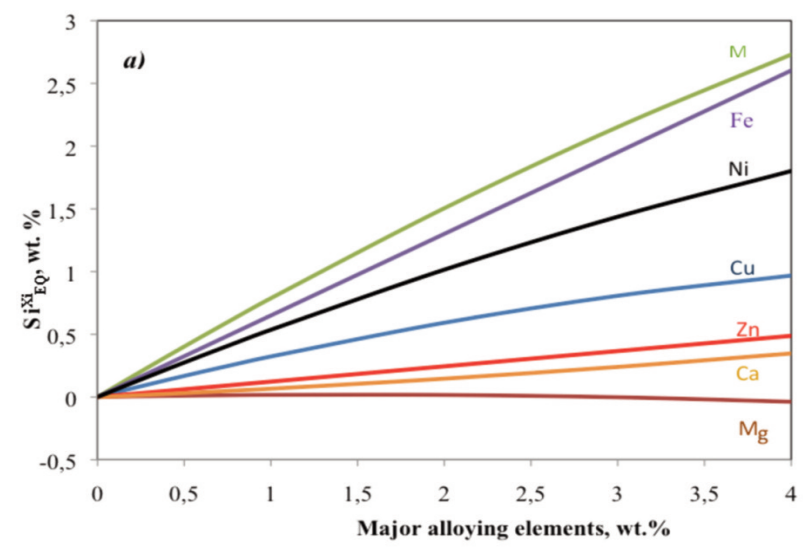

Figure 3 a). Effect of major alloying elements on $\mathrm{Si}^{\mathrm{Xi}}{ }_{\mathrm{EQ}}$ for hypoeutectic alloys.

Figura 3 a). Efecto de los principales elementos de aleación en el SiXi ${ }_{E Q}$ para aleaciones hipoeutécticas. been presented on figure $3 \mathrm{~b}$ ). It is interesting to note the similar effect of grain refiners (titanium and boron), silicon modifiers (strontium and antimony) and low melting points elements (bismuth and lead) on the increase or decrease of the $\mathrm{Si}^{\mathrm{Xi}}{ }_{\mathrm{EO}}$ value.

The $\mathrm{Si}_{\mathrm{EQ}}$ for alloying elements, as well as for some impurity elements, can be determined as the sum of individual contributors $\left(\sum \mathrm{Si}_{\mathrm{X}}{ }_{\mathrm{XQ}}\right)$ plus the effect of silicon itself, and can be expressed as follows:

$$
S i_{E Q}=S i+\Sigma S i_{E Q}^{X i}
$$

The solidification characteristic temperatures for multi-component Al-Si series of alloys can be calculated using following equations:

$$
\begin{gathered}
\mathrm{T}_{\mathrm{LIQ}}^{\mathrm{Al}-\mathrm{Si}-\mathrm{i}}=660.452-6.11 \cdot \mathrm{Si}_{\mathrm{EQ}}-0.057 \cdot \mathrm{Si}_{\mathrm{EQ}}{ }^{2} \\
\mathrm{~T}^{\mathrm{AISi}}{ }_{\mathrm{E}}=660.452-\left(\left(6.11 \cdot \mathrm{Si}_{\mathrm{EQ}}+\right.\right. \\
\left.0.057 \cdot \mathrm{Si}_{\mathrm{EQ}}{ }^{2}\right) \cdot 12.3 / \mathrm{Si}
\end{gathered}
$$$$
\mathrm{T}_{\mathrm{E}}^{\mathrm{Al}-\mathrm{Si}-\mathrm{Cu}}=\mathrm{T}_{\mathrm{LIQ}}-\left(6.11 \cdot \mathrm{Si}_{\mathrm{EQ}}-0.057 \cdot \mathrm{Si}_{\mathrm{EQ}}{ }^{2}\right) \cdot
$$$$
12.3 / \mathrm{Si}
$$

Using the $\mathrm{Si}_{\mathrm{EQ}}$ method some other thermophysical properties, such as fraction solid latent heat ${ }^{[9]}$ and grain growth restriction factor, can also be calculated.

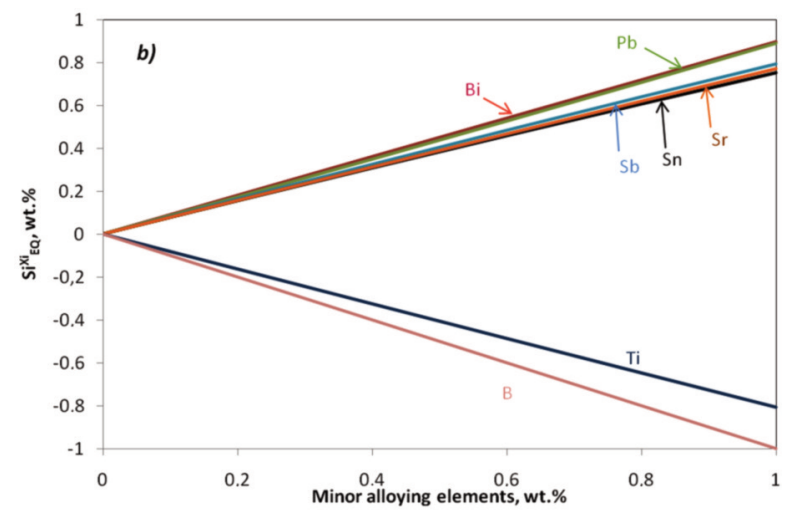

Figure $3 \mathbf{b}$ ). Effect of minor alloying elements on $\mathrm{Si}^{\mathrm{Xi}}{ }_{\mathrm{EQ}}$ for hypoeutectic alloys.

Figura 3 b). Efecto de los elementos minoritarios de aleación en el SiXi ${ }_{E Q}$ en las aleaciones hipoeutécticas. 


\subsection{Literature review of equations for calculation of characteristic solidification temperatures for aluminum alloys}

In the available literature some equations are found to calculate of the liquidus temperature of iron base melts from their known chemical composition. Unfortunately, there are only two published equations to calculate the liquidus temperature for multi-component aluminum alloys. These equations are shown below and they will be compared with the newly developed equations based on $\mathrm{Si}_{\mathrm{EQ}}$ algorithm.

The best known equation for calculating the liquidus temperature of aluminum alloys $\left(\mathrm{T}_{\mathrm{LIQ}}\right)$, based on their known chemical compositions, was developed by Drossel ${ }^{[1]}$, using multiple regression analysis of the experimental data:

$$
\begin{gathered}
\mathrm{T}_{\mathrm{LIQ}}=661-4.97 \mathrm{Si}-0.15(\mathrm{Si})^{2}-6.13 \mathrm{Cu}- \\
\text { 17.4 Mg }+2.72 \mathrm{Zn}+5.08 \mathrm{CuMg}
\end{gathered}
$$

Unfortunately its applicability is limited because equation (9) is valid only for the following ranges of chemical compositions (expressed in wt.\%):

$$
\begin{gathered}
\mathrm{Si} \leq 9.30 ; \mathrm{Cu} \leq 2.50 ; \mathrm{Mg} \leq 0.60 ; \mathrm{Fe} \leq 1.15 \\
\mathrm{Mn} \leq 0.40 ; \mathrm{Zn} \leq 0.63 ; \mathrm{Ni} \leq 0.43 ; \mathrm{Ti} \leq 0.05
\end{gathered}
$$

The next equation for predicting $\mathrm{T}_{\mathrm{LIQ}}$ of aluminum alloys, for $\mathrm{Al}-\mathrm{Si}-\mathrm{Cu}$ systems, has been developed by Vijayaraghavan et al. ${ }^{[2]}$. Using the data from the ternary $\mathrm{Al}-\mathrm{Si}-\mathrm{Cu}$ phase diagram and applying the multiple regressions analysis the following mathematical relation has been obtained:

$$
\mathrm{T}_{\text {LIQ }}=664-6.9 \mathrm{Si}-2.5 \mathrm{Cu}
$$

Equation (10), based only on aluminum, silicon and copper concentrations, fails because it don't takes into account the potentially important influence of other components (for example magnesium, manganese, iron, zinc and titanium) and a substantial error may be produced. This is evident from the fact that the equation's constant $\left(664^{\circ} \mathrm{C}\right)$ is considerably higher than the known melting point of pure aluminum $\left(660.452^{\circ} \mathrm{C}\right)$.

The available literature provides two equations developed by Mondolfo ${ }^{[3]}$ and Gruzleski ${ }^{[4]}$ that can be used to calculate the Al-Si eutectic growth temperature of Al-Si series of aluminum alloys. These equations are based on the effect of melt chemical composition on the depression of the Al-Si eutectic temperature. The effect of each particular element has been derived using literature data and the authors' own experimental data:

$$
\begin{gathered}
\text { TISi }_{E}^{\mathrm{A}}=577-(12.5 / \mathrm{Si}) *(4.43 \mathrm{Mg}+1.43 \mathrm{Fe}+ \\
1.93 \mathrm{Cu}+1.7 \mathrm{Zn}+3.0 \mathrm{Mn}+4.0 \mathrm{Ni}) \\
\mathrm{T}_{\mathrm{E}}^{\mathrm{AlSi}}=660.452-\left(6.11 \mathrm{Si}+0.057 \mathrm{Si}^{2}\right) \\
(12.6 / \mathrm{Si})-(3.4 \mathrm{Cu}+1.34 \mathrm{Fe}+6.3 \mathrm{Mg}+ \\
1218.9 \mathrm{Sr}-32965 \mathrm{Sr}^{2}-4.293 \mathrm{Sb}+ \\
\left.186.3 \mathrm{Sb}^{2}-495.5 \mathrm{Sb}^{2}\right)
\end{gathered}
$$

all the elements are expressed in weight percentages.

In the literature there are no equations for calculating the $\mathrm{Al}-\mathrm{Si}-\mathrm{Cu}$ eutectic temperature or the solidus temperature for the Al-Si series of alloys.

\section{EXPERIMENTAL PROCEDURE}

\subsection{Materials}

Twelve synthetic Al-Si compositions were made by melting a charge of Al-5 wt.\% Si, Al-7 wt.\% Si, Al-9 wt.\% Si and Al-11 wt.\% Si base alloys and adding 1, 2 and 4 wt.\% $\mathrm{Cu}$. The chemical compositions of the resulting alloys, as determined using Optical Emission Spectroscopy (OES) are presented in table I.

\subsection{Melting Procedure}

The alloys were melted in a reverberatory furnace. During processing, the melt was covered with a protective nitrogen gas atmosphere to prevent hydrogen and oxygen contamination. No grain refining agents were added to the melt. The ingots were pre-modified with strontium.

\subsubsection{Thermal Analysis (TA) Procedure}

Samples with masses of approximately $300 \mathrm{~g} \pm 10 \mathrm{~g}$ were poured into stainless steel cups. Two specially designed supersensitive $K$ type thermocouples were inserted into the melt and temperatures between $750-400^{\circ} \mathrm{C}$ were recorded. The data for TA was collected using a high-speed National Instruments Data Acquisition system linked to a personal computer. Each TA trial was repeated three times. Consequently, a total of 36 samples were gathered. 
DESCRIPTION OF HYPOEUTECTIC AL-SI-CU ALLOYS BASED ON THEIR KNOWN CHEMICAL COMPOSITIONS DESCRIPCIÓN DE LAS ALEACIONES HIPOEUTÉCTICAS AL-SI-CU BASADA EN SU COMPOSICIÓN QUÍMICA

Table I. Chemical compositions (wt.\%) of the experimental synthetic aluminum alloys and their characteristic $T_{L I Q}$ and $T_{E}^{A I S i}$ temperatures measured using the thermal analysis technique (note that only major alloying elements are summarized)

Tabla I. Composición química (\% en peso) de las aleaciones experimentales de aluminio y sus temperaturas características $T_{L I Q}$ y $T^{A I S I}$ medidas empleando la técnica del análisis térmico (observar que sólo están incluidos los porcentajes de los elementos principales de aleación)

\begin{tabular}{lccccccccc}
\hline Alloy & Si & Cu & Fe & Mg & Mn & Zn & T $_{\text {LIQ }}$ & TAISi $_{\text {E }}$ & TAISiCu $_{\text {E }}$ \\
\hline AlSi5Cu1 & 4.85 & 1.03 & 0.14 & 0.27 & 0.01 & 0.01 & 626.6 & 572.4 & 543.6 \\
AlSi5Cu2 & 5.01 & 2.06 & 0.13 & 0.25 & 0.01 & 0.01 & 622.8 & 569.2 & 534.5 \\
AlSi5Cu4 & 4.89 & 3.85 & 0.13 & 0.26 & 0.01 & 0.01 & 618.3 & 562.4 & 512.5 \\
AlSi7Cu1 & 7.13 & 0.96 & 0.14 & 0.28 & 0.01 & 0.01 & 613.3 & 573.1 & 526.0 \\
AlSi7Cu2 & 7.05 & 1.98 & 0.13 & 0.28 & 0.01 & 0.01 & 610.0 & 569.1 & 508.0 \\
AlSi7Cu4 & 6.75 & 4.38 & 0.14 & 0.28 & 0.01 & 0.01 & 604.6 & 569.3 & 509.6 \\
AlSi9Cu1 & 9.16 & 1.05 & 0.14 & 0.27 & 0.01 & 0.01 & 597.3 & 572.4 & 516.3 \\
AlSi9Cu2 & 9.02 & 2.44 & 0.12 & 0.27 & 0.01 & 0.01 & 589.9 & 570.2 & 506.5 \\
AISi9Cu4 & 9.45 & 4.38 & 0.14 & 0.27 & 0.01 & 0.01 & 584.4 & 566.4 & 502.8 \\
AlSi11Cu1 & 10.84 & 0.94 & 0.14 & 0.27 & 0.01 & 0.01 & 579.4 & 574.5 & 509.3 \\
AlSi11Cu2 & 10.92 & 1.95 & 0.14 & 0.26 & 0.01 & 0.01 & 576.7 & 573.2 & 501.6 \\
AlSi11Cu4 & 10.55 & 4.36 & 0.13 & 0.27 & 0.01 & 0.01 & 567.7 & NA & NA
\end{tabular}

\section{RESULTS AND DISCUSSION}

Numerical solidification models have become an important tool for increasing quality and reducing production costs of cast parts. These numerical models offer a great potential for improving product quality and leading to a better understanding of the physics of solidification. Without accurate input data the predictions of the models are meaningless. Presently there is a lack of accurate thermo-physical properties data for most of the Al-Si series of aluminum alloys. Therefore, the purpose of this paper was to develop a mathematical/analytical model for calculation the solidification characteristic temperature for hypo Al-Si alloys based on their chemical compositions.

In order to evaluate statistically the accuracy of equations ((6)-(11)), an additional twelve alloys (see table II) were chosen from the literature ${ }^{[4,10-19]}$. The main purpose for taking into consideration all 24 alloys (12 alloys from the literature and 12 alloys from the current experiments) was to prove statistically the reliability of the newly developed silicon equivalency concept and to check the accuracy of newly developed equations ((6)-(8)) over a wide chemical range. All calculated liquidus temperatures are compared with measured temperatures, and the corresponding statistical parameters of this data are presented in table III.
Table III summarizes the following statistical parameters: multiple regression correlation coefficients $-R^{2}$, standard deviation - $\sigma$, average values, minimum and maximum differences between calculated and measured temperatures.

Table III shows that the all three equations used to calculate the liquidus temperature of the $\mathrm{Al}-\mathrm{Si}$ series of aluminum alloys according to the $\mathrm{R}^{2}$ criteria shows acceptable predictions. Statistical analysis reveals that the application of equations (9) and (10) to calculate the liquidus temperature results in a higher standard deviation and are more scatter in the predictions compared to the proposed model equation (6).

Equation (9) developed by Drossel is less accurate than the other two equations, (6) and (10). One of the reasons for this is the fact that this equation is valid only for the following ranges of chemical alloy compositions (expressed in weight percent):

$$
\begin{gathered}
\mathrm{Si} \leq 9.30 ; \mathrm{Cu} \leq 2.50 ; \mathrm{Mg} \leq 0.60 ; \mathrm{Fe} \leq 1.15 \\
\mathrm{Mn} \leq 0.40 ; \mathrm{Zn} \leq 0.63 ; \mathrm{Ni} \leq 0.43 ; \mathrm{Ti} \leq 0.05
\end{gathered}
$$

Therefore, applicability is limited to alloys that have chemical compositions out of above mentioned ranges.

Vijayaraghavan's equation (10), which shows statistically better results than Drossel's equation (9) is limited because it applies only alloys for which $\mathrm{T}_{\mathrm{LIQ}}$ 
Table II. Chemical compositions (wt.\%) of Al-Si alloys and their characteristic $\mathrm{T}_{\mathrm{LIQ}}$ and $\mathrm{T}_{\mathrm{NUC}, \mathrm{E}}^{\mathrm{AIS}}$ temperatures measured using the thermal analysis technique

Tabla II. Composición química (\% en peso) de las aleaciones Al-Si y sus temperaturas características $T_{L I Q}$ y $T_{N U C, E}^{A I S i}$ medidas usando la técnica del análisis térmico

\begin{tabular}{llllllllll}
\hline Lit & Si & Cu & Fe & Mg & Mn & Zn & T LIQ & TAISi $_{\text {E }}$ & TAISiCu $_{E}$ \\
\hline$[10]$ & 6.823 & 1.562 & 0.10 & 0.458 & 0 & 0.01 & 613.6 & 572.3 & NA \\
{$[10]$} & 7.034 & 2.325 & 0.08 & 0.503 & 0 & 0.01 & 610.8 & 571.6 & NA \\
{$[10]$} & 7.362 & 3.693 & 0.10 & 0.491 & 0 & 0.02 & 606.7 & 568.0 & NA \\
{$[11]$} & 5.10 & 2.91 & 0.30 & 0.27 & 0.05 & 0.03 & 622.8 & 567.2 & NA \\
{$[11]$} & 5.75 & 3 & 0.31 & 0.30 & 0.05 & 0.04 & 615.7 & NA & NA \\
{$[12]$} & 12 & 3.39 & 0.20 & 1.55 & 0.01 & 0.03 & 565.7 & NA & NA \\
{$[13]$} & 6.05 & 2.99 & 0 & 0.27 & 0 & 0.03 & 614 & NA & NA \\
{$[13]$} & 7 & 0.003 & 0.05 & 0.35 & 0.01 & 0.02 & 612.8 & NA & NA \\
{$[14]$} & 9.2 & 0.01 & 0.26 & 1.28 & 0.06 & 0.06 & 592 & 576.0 & NA \\
{$[14]$} & 9.3 & 2.6 & 0.52 & 0.59 & 0.11 & 0.51 & 585 & 566.0 & 492.0 \\
{$[4]$} & 5.9 & 3.3 & 0.21 & 0.01 & 0.02 & 0.07 & 616 & 563.8 & 520.0 \\
{$[4]$} & 5.01 & 1.4 & 0.22 & 0.52 & 0.02 & 0.02 & 622 & 570.0 & 540.0 \\
\hline
\end{tabular}

Table III. Regression coefficients, standard deviations and average values of the liquidus temperature calculated using the silicon equivalency method and the method developed by other authors

Tabla III. Coeficientes de regresión, desviación estándar y valores medios de la temperatura de liquidus calculados usando el método del silicio equivalente y los métodos desarrollados por otros autores

\begin{tabular}{lccccc}
\hline Statistical Data & & T $_{\text {LIQ }}$ & & T $^{\text {AISi }}{ }_{\text {E }}$ & T $^{\text {AlSiCu }}{ }_{\text {E }}$ \\
\hline Equation \# & \multicolumn{1}{c}{$(6)$} & $(9)$ & $(10)$ & $(7)$ & $(8)$ \\
$\mathrm{R}^{2}$ & 0.98 & 0.95 & 0.97 & 0.88 & 0.77 \\
Standard Deviations & 2.81 & 3.89 & 3.33 & 1.39 & 7.26 \\
Average Value & -1.75 & 5.75 & -2.40 & -1.07 & -0.09 \\
Minimum & -5.63 & -1.96 & -8.49 & -2.96 & -14.03 \\
Maximum & 2.08 & 12.33 & 2.73 & 2.77 & 10.62 \\
\hline
\end{tabular}

can be estimated using only aluminum, silicon and copper concentrations as independent variables. It doesn't take into account the potential important influence of other elements (e.g. magnesium, manganese, iron, zinc and titanium). Therefore, a substantial error is created in the estimation of liquidus temperature in those cases where the elements mentioned above have a considerable influence. This is evident from the fact that the equation's constant $\left(664^{\circ} \mathrm{C}\right)$ is considerably higher than the known melting point of pure aluminum $\left(660.452^{\circ} \mathrm{C}\right)$.

Figures 4, 5 and 6 plot the solidification characteristic temperatures for every aluminum alloys presented in table I and table II versus their experimentally determined counterparts using equations (6), (7) and (8). The experimental temperatures have been measured using thermal analysis technique.

The cooling curves and their first derivative have been used to determine the values of characteristic liquidus temperatures for each particular chemical composition of the alloys presented in table I. For the same chemical composition the value of liquidus temperatures have been also calculated using the $\mathrm{Si}_{\mathrm{EQ}}$ method. Factsage, Thermocalc and Pandat softwares have been also used to calculate liquidus temperature. Figure 7 shows the comparison between the liquidus temperature of measured values and the calculated 


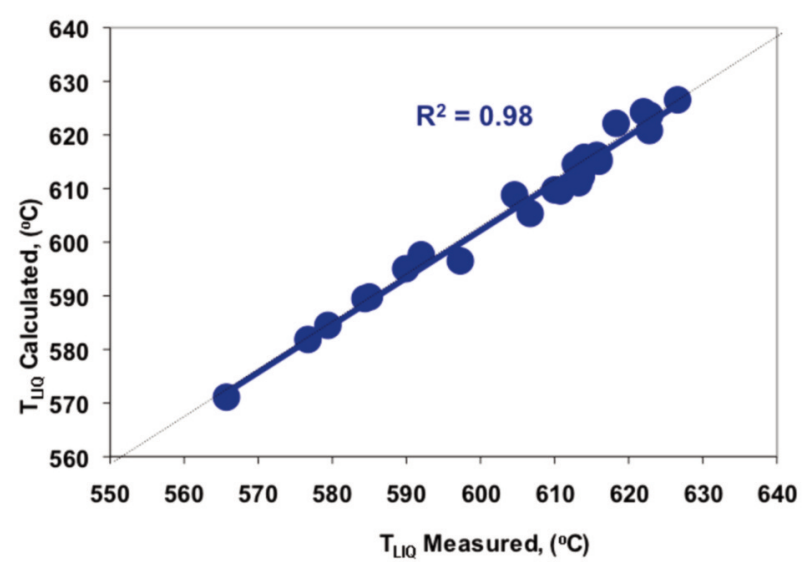

Figure 4. Calculated versus measured liquidus temperature using equation (6).

Figura 4. Temperatura de liquidus medida versus la calculada usando la ecuación (6).

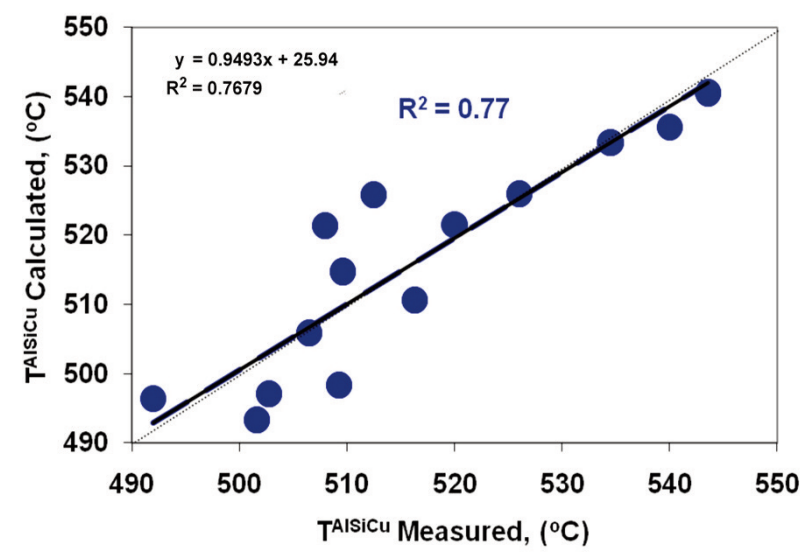

Figure 6. Calculated versus measured $\mathrm{Al}-\mathrm{Si}-\mathrm{Cu}$ eutectic nucleation temperature using equation (8).

Figura 6. Temperatura de nucleación eutéctica Al-Si-Cu medida versus la calculada con la ecuación (8).

values obtained by applying software packages. This figure 7 shows very good agreement between all procedures.

The accuracy of the calculated liquidus temperature in the proposed model equation (6) is dependent solely on the accuracy of the coefficients, by means of which corresponding alloy content is converted into an equivalent silicon weight percent. However, these coefficients are derived from the liquidus lines in the respective binary systems, and their reliability is closely related

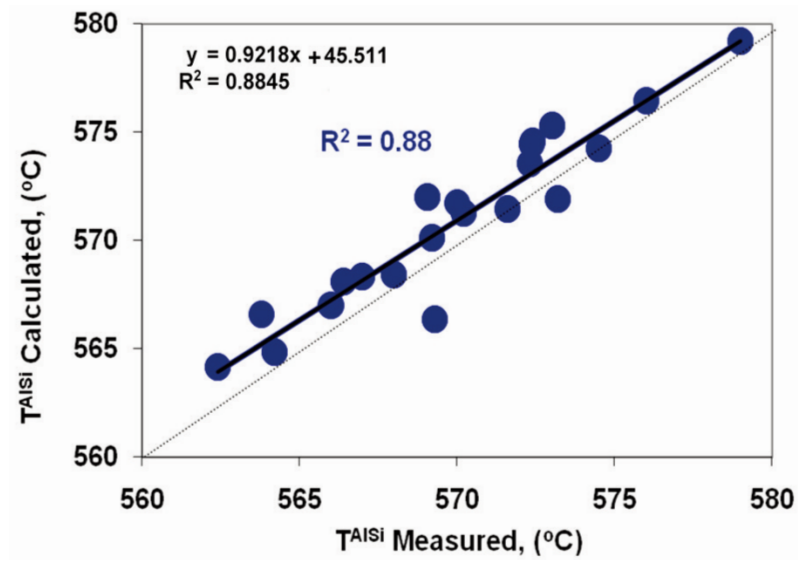

Figure 5. Calculated versus measured Al-Si eutectic nucleation temperature using equation (7).

Figura 5. Temperatura de nucleación eutéctica Al-Si medida versus la calculada usando la ecuación (7).

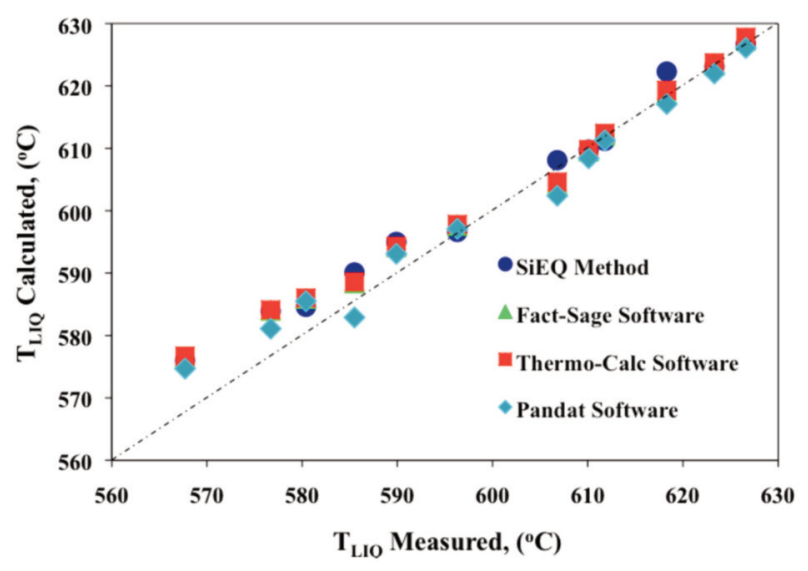

Figure 7. Calculated versus measured liquidus temperature obtained using various analytical approaches.

Figura 7. Temperatura de liquidus medida versus las obtenidas usando varias aproximaciones analíticas.

to the accuracy with which the liquidus curves are experimentally determined and numerically fitted. Therefore, some inaccuracy is also observed by applying this method. In order to exclude this source of error a re-examination of liquidus lines on the silicon rich side of the respective binary systems or even better for the ternary Al-Si-Xi system would be necessary.

Another advantage of a new $\mathrm{Si}_{\mathrm{EQ}}$ method can be recognized in its application to calculate both eutectic temperatures in the Al-Si series of alloys. Potentially, 
a similar approach could be used to develop an equation for calculation of the solidus temperature of aluminum multi- component alloys.

\subsection{Application of the $\mathrm{Si}_{\mathrm{EQ}}$ procedure: calculation of the latent heat}

The latent heat of solidification is a thermo-physical property of a material. During the solidification process every substance releases a certain amount of heat that characterizes the substance. By definition, latent heat is the energy required to solidify $1 \mathrm{~kg}$ of a liquid, expressed in $\mathrm{J} / \mathrm{g}$ or $\mathrm{J} / \mathrm{mol}$. The mathematical modeling and simulation of the solidification process of metals and alloys is inaccurate without the knowledge of this property. Therefore, there is always a necessity to show the value of the latent heat of any alloy in advance. For pure metal accurate data is available from bibliography to obtain the latent heat value $^{[20]}$. There are some information about the latent heat evolution during solidification of binary aluminum, lead-tin, nickel-zirconium based alloys ${ }^{[16,21}$ and 22$]$. Unfortunately, there is no an easy way to get the value for latent solidification heat of multi-component alloys that solidify in a given temperature range (mushy zone), either using measured techniques or calculated procedures. For any alloy which solidify in a given temperature range, the evolution of the latent heat begins at the liquidus temperature. The release of the latent heat continues until the alloy reaches its solidus temperature. In the mushy zone (the region between the liquidus and the solidus temperature), the substance is neither in a totally liquid phase nor in a totally solid phase, but is a mixture containing a fractional amount of both liquid and solid. Several models of latent heat release have already been proposed for modeling of casting solidification. These models include the linear and quadratic releases of latent heat between the liquidus and solidus temperatures, as well as the use of the Lever Rule and Scheil's equation ${ }^{[18]}$. Each of these models assumes that the amount of latent heat released is proportional to the increase of solid fraction in the casting. The latent solidification heat of any alloy depends on its chemistry and the microstructure developed during the solidification process. The solidification path of these alloys was observed and the corresponding latent heat released during solidification was measured using a Differential Scanning Calorimeter (DSC).

Applying the silicon equivalency method to multicomponent aluminum alloys can be considered as pseudo binary $\mathrm{Al}-\mathrm{Si}_{\mathrm{EQ}}$ alloys. In this case the solidification path of these alloys can be described through formation of a primary $\alpha-\mathrm{Al}$ solid solution and through precipitation of the Al-Si eutectic (secondary aluminum and primary silicon). Applying the $\mathrm{Si}_{\mathrm{EQ}}$ method, the multi-component aluminum alloys are transferred into a recognized $\mathrm{Al}-\mathrm{Si}_{\mathrm{EQ}}$ pseudo binary system. Using the Lever Rule the primary $\alpha-\mathrm{Al}$ amount can be calculated, assuming that the precipitated $\alpha-\mathrm{Al}$ solid solution has the same value for latent solidification heat as pure aluminum. Applying the same principle the amount of secondary aluminum present in the remaining eutectic as well as the amount of primary silicon can be calculated. For nonequilibrium solidification conditions the Scheil's equation could be applied to calculate the amount of solid fraction of primary and eutectic phases.

When the latent heat has been released under the equilibrium condition, the latent heat of solidification can be calculated as follows:

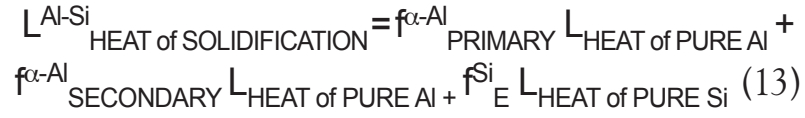

The solidification path of $12 \mathrm{Al}$ alloys from table I and their corresponding latent heats released during solidification process have been also experimentally determined and measured using a Differential Scanning Calorimeter (DSC) apparatus. The latent solidification heat has been measured taking into consideration the area between the DSC curve and base line. This area is proportional to the latent heat energy released during solidification. For the same chemical composition the value of latent heat has also been calculated using the novel $\mathrm{Si}_{\mathrm{EQ}}$ method proposed in this work. Figure 8 shows the comparison between the measured values of latent solidification heat and the calculated values obtained by applying the novel algorithm for calculation of the latent heat.

The results presented in figure 8 show a close agreement between calculated and experimental values for latent heat. The high standard correlation $\left(R^{2}=0.9\right)$ confirms that it is possible to estimate the latent solidification heat of aluminum alloys series that solidified under equilibrium conditions using the novel method based on the $\mathrm{Si}_{\mathrm{EQ}}$ algorithm.

\subsection{Application of the $\mathrm{Si}_{\mathrm{EQ}}$ procedure: calculation of the Growth Restriction Factor}

Grain refinement has been widely accepted in aluminum casting plant as a standard used to reduce the grain size in as cast structure. The grain refining 


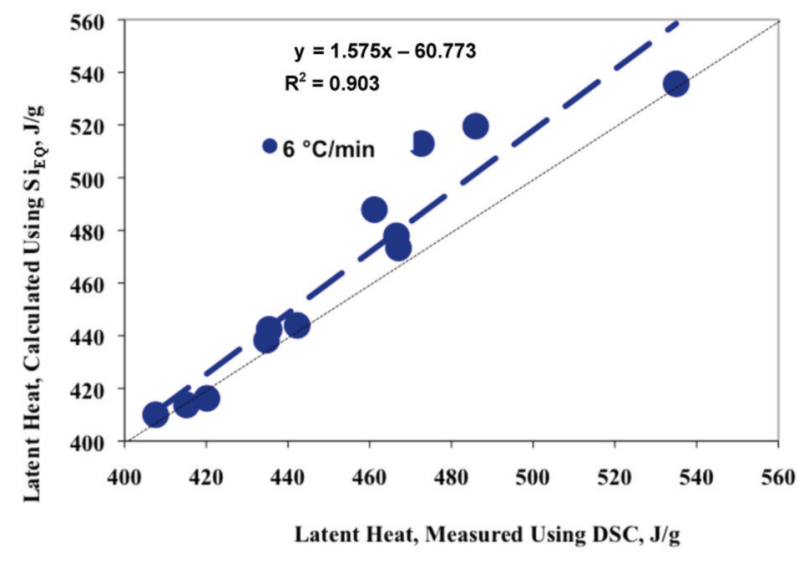

Figure 8. Comparison between the measured and calculated value of latent heat for the aluminum-alloys taken from table I.

Figura 8. Comparación entre el valor del calor latente medido y el calculado para las aleaciones de aluminio de la tabla I.

mechanism can be divided into two types. First type assumes that nucleation particles are of ultimate importance while second type recognizes solute as essential for the achievement of the fine grained microstructure $^{[19,23-25]}$. Much of the literature about grain refinement concerns the efficiency of different nucleating particles and much less effort has been devoted to clarify how solute in the melt influences the structure development during solidification. Solute theory, formalized by Backerud and Johnsson ${ }^{[15}$ and 24$]$, suggest that nucleants and the segregation influence the grain refinement. The degree of segregation is measured in terms of a Growth Restriction Factor (GRF). The GRF is a measure of the growth restricting effect of solute elements on the growth of solid-liquid interface of the new grains as they grow into the melt. Based on the binary Al-Xi system the GRF is defined as $\mathrm{m}(\mathrm{k}-1) \mathrm{C}_{\mathrm{O}}$, where $m$ is the slope of the liquidus, $\mathrm{C}_{\mathrm{O}}$ is the concentration of the solute in the melt, and $\mathrm{k}\left(=\mathrm{C}_{\mathrm{S}} / \mathrm{C}_{\mathrm{L}}\right.$, where $\mathrm{C}_{\mathrm{S}}$ and $\mathrm{C}_{\mathrm{L}}$ are the solute concentrations of the solid and liquid respectively at the interface) is the equilibrium partitioning coefficient. Recently, it has been suggested that GRF can be also calculated using $\mathrm{Si}_{\mathrm{EQ}}$ approach. Equation (12) shows relationship between $\mathrm{Si}_{\mathrm{EQ}}$ and the GRF for hypoeutectic aluminum alloys:

$$
\mathrm{GRF}=\mathrm{m}_{\mathrm{Si}}\left(\mathrm{k}_{\mathrm{Si}}-1\right) * \mathrm{Si}_{\mathrm{EQ}}
$$

Figure 9 shows relationship between the chemistry of aluminum alloys (expressed in the value of $\mathrm{Si}_{\mathrm{EQ}}$ ) and their corresponding GRF calculated using either equation (12) or applying Backerud approach (GRF

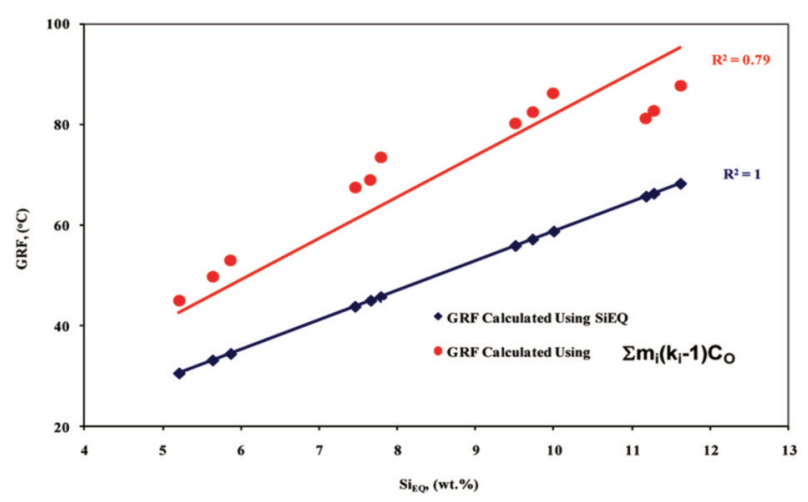

Figure 9. Relationship between GRF and chemistry of the aluminum alloys taken from table I.

Figura 9. Relación entre GRF y composición química de las aleaciones de aluminio obtenidas de la tabla I.

has been calculated as $\sum \mathrm{m}_{\mathrm{i}} \mathrm{C}_{\mathrm{O}}(\mathrm{k}-1)$ of all elements). Statistical analysis revealed a considerably higher level of fittingness between chemistry and the calculated values of GRF by using the $\mathrm{Si}_{\mathrm{EQ}}$ methodology $\left(\mathrm{R}^{2}=1.0\right)$ in comparison with traditional method, which use the sum of individual factor for each element $\left(R^{2}=0.79\right)$. The advantage of the new method based on the $\mathrm{Si}_{\mathrm{EQ}}$ in comparison to traditional one based on the sum of individual alloying elements can be recognized in its simplicity and accuracy. The bulk chemistry of the aluminum alloy, the slope of the liquidus line and partition coefficient of the Al-Si binary alloy is necessary as input data. All these data are easy available and can be highly accurate derived from binary system. Using the $\mathrm{Si}_{\mathrm{EQ}}$ concept some uncertainty regarding the accuracy of $\mathrm{Al}-\mathrm{Xi}$ binary systems i.e., their corresponding $\mathrm{m}_{\mathrm{i}}$ and $\mathrm{k}_{\mathrm{i}}$ values, can be eliminated.

\section{CONCLUSIONS}

- A novel $\mathrm{Si}_{\mathrm{EQ}}$ method has been used to calculate the liquidus temperatures of hypo multicomponent Al-Si alloys. The calculation procedures presented in this paper are more accurate than those found in the literature.

- Experiments have been carried out to observe the effect of chemistry of the series of aluminum alloys ( $\mathrm{Si}=5,7,9$ and $11 \mathrm{wt} . \%$ and $\mathrm{Cu}=1,2$ and $4 \mathrm{wt} . \%)$ and the cooling rate $\left(6^{\circ} \mathrm{C} / \mathrm{min}\right)$ on the amount of released latent heat during solidification. 
- In this paper a novel method to calculate quickly the latent solidification heat of aluminum alloys series has been developed. The model is based on the assumption that the latent heat of the alloy is released at a rate proportional to the formation of the alloy solid fraction during solidification.

- Multi-component aluminum alloys have been analyzed as pseudo binary alloys by applying the already developed method of silicon equivalency. The results of these calculations were found to be fairly accurate in comparison to the measured values. It was noted that the possibility for accuracy improvement of the calculated latent heat values by including the effect of interaction among elements from the aluminum melt is still needed.

- According to the measured and calculated latent heat values for the $\mathrm{Al}-\mathrm{Si}$ - $\mathrm{Cu}$ series of aluminum alloys, the latent heat of solidification is strongly dependent on the silicon content and only slightly dependent on the copper content.

- The calculated value of the GRF by using $\mathrm{Si}_{\mathrm{EQ}}$ algorithm potentially can be applied to predict the grain size of cast aluminum alloys.

\section{REFERENCES}

[1] G. Drossel, Giessereitechnik 27 (1981) 7.

[2] R. Vijayaraghavan, N. Pelle, J. Boileau, J. Zindel and R. Beals, Scripta Mater. 35 (1996) 861.

[3] L.F. Mondolfo, Aluminum Alloys, Structure and Properties, Ed. Butterworths, London, England, 1979, pp. 213-614.

[4] N. Tenekedjiev, H. Mulazimoglu, B. Closset and J. Gruzleski, Microstructures and Thermal Analysis of Strontium Treated Aluminum Silicon Alloys, American Foundrymen's Society, Inc. Des Plaines, Illinois, EE.UU., 1995, pp. 1-76.

[5] ASM Handbook Vol. 3, Alloy Phase Diagrams, J.R. Davis, The Materials Information Society, EE.UU., 1992.

[6] R.J. Kissing and J.F. Wallace, Foundry 69 (1963) 74.

[7] O.G. Wang and J.C. Davidson, J. Mater. Sci. 36 (2001) 739.

[8] J. Barthel, R. Göbel and M. Jurisch, J. Cryst. Growth 52 (1981) 369.
[9] M.B. Djurdjevic, J. Sokolowski, W. Kierkus and G. Byczynski, Mater. Sci. Forum 539-543 (2007) 299-304.

[10] M.B. Djurdjevic, W.T. Kierkus, G.E. Byczynski and J.H. Sokolowski, AFS Transactions 47 (1998) 143-147.

[11] A. Kearney, Proceedings from the Conference on Thermal Analysis of Molten Aluminum, Rosemont, Illinois, EE.UU., 1984, p.169.

[12] J. Carbonier and C. Rechiney, Proceedings from the Conference on Thermal Analysis of Molten Aluminum, Rosemont, Illinois, EE.UU., 1984, p.121.

[13] B.P. Winter, T.R. Ostram, T.A. Sleder, P.K. Trojan and R.D. Pehlke, AFS Transactions 87 (1993) 259.

[14] A.N. Lakshmanan, S.G. Shabestari and J.E Gruzelski, Z. Metallkd. 86 (1995) 457-464.

[15] L. Backenrud, G. Chai and J. Tamminen, Solidification Characteristics of Aluminum Alloys, Vol. 2, Foundry Alloys, AFS/Skan aluminium, Oslo, Norway, 1986.

[16] V.T.Witusiewicz and F. Sommer, Metall. Mater.Trans. 31 (2000) 277-284.

[17] M.B. Djurdjevic, Mater. Sci. Forum 539-543 (2007) 229-304.

[18] M.B. Djurdjevic, W.T. Kierkus, G.E. Byczynski, T.J. Stockwell and J.H. Sokolowski, AFS Transactions 14 (1999) 173.

[19] B.S. Murty, S.A. Kori and M. Chakraborty, Int. Mater. Rev. 47 (2002) 3-29.

[20] ASM Specialty Handbook, Aluminum and Aluminum Alloys; Ed. by J.R. Davis, EE.UU.,1994.

[21] S.F. Ares, A.E. Schvezov and C.E Schvezov, Proceedings of Sessions, TMS Annual Meeting, Warrendale, Pennsylvania, EE.UU., 2000, pp. 615-621.

[22] A.E. Ares, S.F. Gueijman and C.E. Schvezov, Proceedings of Sessions, TMS Annual Meeting, Warrendale, Pennsylvania, EE.UU., 2001, pp. 1077-1084.

[23] K.T. Kashyap and T. Chandrashekar, Mater. Sci. 24 (2001) 345-353.

[24] M. Johnsson, Thermochim. Acta 256 (1995) 107-121.

[25] M. A. Easton and D.H. St. John. Acta Mater. 49 (2001)1867-1878. 